\title{
Pengelolaan Digital Public Relations Rumah Sakit “JIH” Yogyakarta Tahun 2017
}

\author{
Yusuf Efendi Nasution ${ }^{1}$ dan Tri Hastuti Nur $\mathbf{R}^{* 2}$ \\ ${ }^{1,2}$ Universitas Muhammadiyah Yogyakarta \\ Email: iyusufefendi@gmail.com, trihastuti.aisyiyah@gmail.com* \\ *corresponding author
}

Key Word:

Digital Public Relations

Planning

Organizing

Evaluation

JIH Hospital

Kata Kunci :

Digital Public Relations

Perencanaan

Pengelolaan

Evaluasi

Rumah Sakit JIH

\begin{abstract}
Information technology is rapidly changing requires the public relations to establish digital public relations in the part of communication strategy of their organizations. This research analyzed the management of digital public relations in one of the healthcare industry in Yogyakarta with the highest number of social media traffic, i.e. "JIH" Hospital. The objective of this research was to describe the management of digital public relations of "JIH" Hospital started from the planning, the implementation until the evaluation in 2017. The research method used was descriptive qualitative with case study approach. The result of the research showed that the planning conducted in 2017 endured changing transition that was brief, spontaneous, and eventual in the beginning, so that it became longer, thematic, and arranged. The message or content planning was based on medical calendar that then was written on editorial plan that became the reference in the implementation activities. The evaluation conducted was based on the data obtained from the social media analysis.
\end{abstract}

\begin{abstract}
ABSTRAK
Transformasi perkembangan teknologi informasi yang semakin pesat mengharuskan bagi para profesional PR untuk mulai menerapkan digital PR dalam kegiatan komunikasi organisasinya. Penelitian ini menganalisis pengelolaan digital public relations di salah satu perusahaan yang bergerak dibidang kesehatan dengan jumlah traffic media sosial tertinggi di D.I Yogyakarta yakni Rumah Sakit "JIH". Tujuan dari penelitian ini adalah untuk mendeskripsikan pengelolaan digital public relations Rumah Sakit "JIH" dimulai dari perencanaan, implementasi hingga evaluasi pada tahun 2017. Metode penelitian yang digunakan adalah deskriptif kualitatif dengan pendekatan studi kasus. Hasil dari penelitian menunjukan bahwa perencanaan yang dilaksanakan pada tahun 2017 mengalami transisi perubahan yang awalnya singkat dan spontanitas hingga menjadi lebih panjang, bertema, dan tersusun. Perancangan pesan atau konten bedasarkan kalender medis kemudian dituangkan pada editorial plan yang menjadi acuan dalam implementasi kegiatan PR. Evaluasi yang dilakukan bedasarkan data yang diperoleh dari analis media sosial.
\end{abstract}

Copyright (C) 2018 Channel Jurnal Komunikasi. All right reserved. 


\section{PENDAHULUAN}

Digital Public Relations atau $e-P R$ atau dapat disebut juga sebagai Cyber Public Relations merupakan konsep baru yang digunakan dalam manajemen reputasi perusahaan. Praktek Digital Public Relations (PR) merupakan salah satu bagian dari kegiatan hubungan masyarakat yang diadaptasi dari penggunaan teknologi informasi dan komunikasi bagi perusahaan. Pentingnya penyebaran informasi digital begitu dirasakan setiap perusahaan atau pemerintah sehingga kesadaran untuk memenuhi kebutuhan informasi pada media tersebut perlu diterapkan pengelolaan yang sesuai dalam penerapannya.

Pertumbuhan pengguna internet di Indonesia menurut hasil survey Asosiasi Penyelenggara Jasa Internet Indonesia pada tahun 2017 telah mencapai 143,26 juta jiwa, yang meningkat pada tahun sebelumnya yaitu pada tahun 2016 berkisar 132,7 juta jiwa maupun pada 2 (dua) tahun silam yang berkisar 110,2 juta jiwa pada tahun 2015. Disebutkan juga pada survey tersebut bahwa pencarian informasi dalam membeli terletak pada tiga besar perilaku pengguna internet bidang ekonomi dengan jumlah 37,82\%. Adapun dijelaskan kembali pada perilaku pengguna internet dalam bidang gaya hidup, pemanfaatan media sosial terletak pada nomor satu dengan angka 87,13\%. (Infografis: Penetrasi \& Perilaku Pengguna Internet Indonesia APJII, 2017).

Data yang dihimpun dari 2.500 PR profesional, utamanya yang menjabat sebagai manajer dan direktur PR di 8 (delapan) negara. Hasil tersebut menyatakan keterlibatan mereka dalam menggunakan Digital PR cukup tinggi. (Berghs School of Communication \& Mynewsdesk. 2016. Global Study Sets Stage For The Digital PR Revolution. Stockholm (2016:3). Studi lain dari Mynewdesk digital PR menjelaskan bahwa setengah dari praktisi PR merasakan dampak dari penggunaan teknologi dalam komunikasi perusahaan dapat terus meningkatkan kemungkinan perusahaan untuk menjangkau pemangku kepentingan (stakeholders) sebanyak 89\%. Kondisi tersebut memungkinkan praktisi PR untuk lebih fokus pada personalisasi dibandingkan dengan komunikasi massa sejumlah $83 \%$ kemudian memberikan PR lebih banyak kendali dan pengawasan terhadap pesan sebanyak $82 \%$. Riset lebih lanjut mendeskripsikan tentang peran Digital PR bagi praktisi PR antara lain digunakan sebagai alat untuk menganalisa 71,4\%, penggunaan email jasa pemasaran $63,2 \%$, pengaturan solusi sosial media $61,8 \%$, penggunaan video dan gambar kreatif $57,4 \%$, kemudian sebagai media monitoring 53,4\% dan lain lain. (2016: 4-6)

Penelitian ini akan menganalisis bagaimana pengelolaan digital PR di rumah sakit JIH didasarkan pada meningkatnya jumlah rumah sakit di Yogyakarta sehingga menyebabkan persaingan ketat untuk mempertahankan kelangsungan perusahaannya. Ketatnya persaingan ini mendorong rumah sakit mengembangkan berbagai strategi; dan salah satunya adalah pengelolaan digital PR. Di tengah sengitnya persaingan industri rumah sakit di D.I Yogyakarta, Rumah Sakit "JIH" tampil lebih unggul dibandingkan dengan rumah sakit yang telah berdiri sebelumnya dan rumah sakit baru yang terus dibangun di Yogyakarta dalam segi informasi digital yang tersedia. (Diakses melalui https://news.detik. com/berita-jawa-tengah/d-3876492/pengusaha-as-tertarik-investasi-rumah-sakit-di-yogyakarta pada tanggal 23 April 2018)

Media platform yang digunakan Rumah Sakit JIH dalam mengelola digital Public Relations antara lain website, facebook, instagram dan twitter. Jika dirunut ke belakang, kegiatan Digital PR Rumah Sakit "JIH” Yogyakarta sudah dimulai awal tahun 2013 pada facebook namun secara garis besar di ketiga akun media sosial yakni facebook, twitter dan instagram yang secara resmi dimilki oleh Rumah Sakit "JIH" mulai aktif pada akhir tahun 2015. Berbeda dengan facebook yang telah mengawali penggunaanya pada kuatral pertama tahun pada bulan Februari 2013, kemudian disusul oleh penggunaan instagram pada awal tahun tepatnya pada bulan November 2015, selanjutnya disertai dengan penggunaan twitter pada bulan berikutnya yaitu pada bulan September 2016.

Pada tahun 2017, pengelolaan digital PR di Rumah Sakit JIH lebih intensif, inovatif dan kreatif dengan menggandeng biro konsultan dalam mengembangkan digital PRnya. Pengelolaaan digital PR ini Rumah Sakit "JIH" berdampak pada meningkatnya kualitas informasi dan arus informasi digital yang ditampilkan melalui berbagai media digital di antara rumah sakit umum di D.I Yogyakarta. Berdasarkan pada data-data di atas maka penelitian ini bertujuan untuk menganalisis bagaimana pengelolaan digital public relations Rumah Sakit “JIH” tahun 2017.

\section{KERANGKA TEORI}

\section{a. Digital Public Relations}

Dalam penggunaan istilah digital Public Relations sendiri sebenarnya terdapat banyak istilah lain yang digunakan namun tetap merujuk kepada pemahaman yang sama mengenai Digital Public Relations seperti istilah new media (media baru), cyber Public Relations, electronic Public Relations (e-PR), online Public Relations, Public Relations 2.0, hubungan masyarakat online (humas online). Menurut Bob J. Onggo (2004:1) pengertian inisiatif PR atau Public Relations yang menggunakan media internet sebagai sarana publikasinya, inisiatif PR ini di Indonesia lebih dikenal dengan istilah $C y b e r$ Public Relations.

Para praktisi PR yang telah menjalankan beberapa kegiatan dalam Digital PR, tentu tidak melepaskan diri dari kegiatan PR yang masih menggunakan strategi secara tradisional atau offline. Menurut Kartikasari (2017:4) banyak praktisi 
PR yang dipengaruhi oleh fenomena dimana media tradisional tergerus oleh media berbasis digital. Namun, di seluruh bagian dunia, peran media tradisional sekalipun sebagian masih eksis dan sangat dibutuhkan. Perbedaan karakteristik antara penggunaan media tradisional dan media digital dalam pemanfataan publisitas bagi praktisi PR merupakan suatu upaya penyesuaian penggunaan berbagai media dalam meraih konsumen yang sesuai dengan target perusahaan.

Tabel 1. Cara Baru dalam berinteraksi dengan Audiens Baru

\begin{tabular}{|l|l|}
\hline \multicolumn{1}{|c|}{ Kemarin } & \multicolumn{1}{c|}{ Sekarang } \\
\hline 1. Komunikasi satu arah & 1. Siklus komunikasi bedasarkan audiens \\
\hline 2. Komunikasi lokal atau regional & 2. Pendengar global \\
\hline 3. Siklus pemberitaan yang terencana & 3. Siklus pemberitaan respon cepat \\
\hline $\begin{array}{l}\text { 4. Perencanaan konferensi pers, rilis media } \\
\text { massa }\end{array}$ & $\begin{array}{l}\text { 4. Strategi esklusif, online konferensi pers untuk } \\
\text { mendukung media pemberitaan }\end{array}$ \\
\hline 5. Strategi komunikasi bedasarkan media & 5. Konstitusi banyak ketika sangat penting \\
\hline 6. Kontrol berita yang terpusat & $\begin{array}{l}\text { 6. Menciptakan pemberitaan dan kampanye viral untuk } \\
\text { disebar }\end{array}$ \\
\hline 7. Satu hingga tiga tahun perencanaan & 7. Satu hingga tiga bulan perencanaan \\
\hline 8. Siklus panjang penelitian & 8. Potret singkat dan siklus penelitian yang adaptif \\
\hline 9. Agen publisitas & 9. Arsitek komunikasi bisnis \\
\hline $\begin{array}{l}\text { 10. Teladan, aturan yang keras, dan cara } \\
\text { manual untuk bekerja }\end{array}$ & $\begin{array}{l}\text { 10. Kewirausahaan, strategi cepat, dan implementasi } \\
\text { akan membawa ke arah mana saja. }\end{array}$ \\
\hline
\end{tabular}

Sumber : Middleberg, Don. (2001: 21)

Perbedaan karakteristik cara berinteraksi dengan audiens baru berkaitan dengan media tradisional dan media berbasis digital, disederhanakan dalam tabel diatas. Melalui tabel dapat diperhatikan poin-poin penting mengapa penggunaan media digital menjadi sangat penting untuk dilaksanakan oleh para praktisi PR, mengingat interaksi yang baru diciptakan oleh audiens mulai dari arah komunikasi yang awalnya hanya satu arah menjadi audiens yang mengatur perputaran komunikasi. Berikut juga mengenai target yang dipastikan pada penggunaan media tradisional yang hanya menjangkau komunikan secara lokal atau regional menjadi secara praktis menjadi audiens yang global. Begitu halnya dengan perencanaan strategi yang apabila menggunakan media tradisional memerlukan waktu berkisar antara satu hingga tiga tahun lamanya, menjadi satu hingga tiga bulan pada penggunaan media digital.

Peranan Digital Public Relations, menurut Bob Julius Onggo (2004: 4-6) PR di media digital mempunyai peranan yang lebih besar dan luas dibandingkan dengan kegiatan PR offline melalui beberapa peranan digital PR bagi perusahaan antara lain jangkauan global, interaktif (komunikasi dua arah), biaya efisien, memelihara reputasi dan menjalin hubungan. Tools yang digunakan pada digital Public Relations menurut Bob J. Onggo (2004:11) dalam strategi untuk meningkatkan brand di mata publiknya antara lain website perusahaan, publisitas situs pencari (google/yahoo), press release online, autoresponder pada e-mail, kartu nama elektronik pada e-mail, e-newsletter, mailing list (forum pada website perusahaan) dan forum (facebook, twitter, instagram dll).

\section{b. Peran Media Sosial dalam Public Relations}

Pemanfaatan digital Public Relations bagi perusahaan tidak akan terlaksana secara maksimal tanpa adanya penggunaan media sosial sebagai alat dalam pelaksanaan kegiatannya. Seperti yang dijelaskan pada bagian sebelumnya pada bagian Forum di Tools Digital Public Relations yakni peran media sosial merupakan bagian yang tidak dapat dipisahkan dalam pelaksanaan kegiatan praktisi Public Relations dalam menjangkau publik di dunia digital. Kehadiran berbagai macam jenis media sosial merupakan sebuah tantangan sebagai seorang praktisi PR untuk mendalami berbagai fitur yang dimiliki oleh media sosial untuk memaksimalkan kehadiran perusahaan atau instansi pada dunia digital.

Tabel 2. Perbandingan PR Traditional dan PR di Media Sosial

\begin{tabular}{|l|l|l|}
\hline & \multicolumn{1}{|c|}{ PR Traditional } & \multicolumn{1}{c|}{ PR di Media Sosial } \\
\hline Posisi khalayak & Sebagai anggota masyarakat atau publik & $\begin{array}{l}\text { - Sebagai anggota masyarakat atau publik } \\
\text { - Sebagai individu }\end{array}$ \\
\hline Model komunikasi & $\begin{array}{l}\text { - Satu arah dan dalam kasus tertentu bisa dua arah } \\
\text { - Cenderung menyebar (broadcast) }\end{array}$ & $\begin{array}{l}\text { Berbagai arah, namun dapat menentukan target } \\
\text { khalayak yang lebih spesifik }\end{array}$ \\
\hline Jenis media & Beragam & $\begin{array}{l}\text { Beragam tergantung jenis media sosial yang } \\
\text { digunakan }\end{array}$ \\
\hline $\begin{array}{l}\text { Akses terhadap } \\
\text { komunikasi }\end{array}$ & $\begin{array}{l}\text { Terbatas pada media yang menginformasikan dan } \\
\text { konten kepada publik cenderung tidak tersimpan }\end{array}$ & $\begin{array}{l}\text { Tidak terbatas dan publik bisa mengakses beragam } \\
\text { konten karena tersimpan dalam database }\end{array}$ \\
\hline $\begin{array}{l}\text { Kebutuhan akan } \\
\text { biaya }\end{array}$ & $\begin{array}{l}\text { Cenderung memerlukan biaya dan terkadang } \\
\text { dalam jumlah besar }\end{array}$ & Biaya bisa ditekan seminimal mungkin \\
\hline
\end{tabular}

Sumber: Nasrullah, Rulli. (2014:174) 
Breakenridge dalam Rulli (2017:173) memberikan catatan khusus terkait pertemuan antara PR dan media sosial. Menurutnya, kehadiran media sosial memberikan peningkatan terhadap teknik-teknik komunikasi, semakin beragamnya praktik PR, serta adanya perubahan terhadap peran maupun fungsi dan tanggung jawab PR. Sebuah perusahaan kini sejatinya tidak bisa mengontrol atau mengendalikan brand yang ada di tengah masyarakat (pasar). Khalayak selaku konsumen maupun bukan, kini yang mengambil alih.

\section{c. Manajemen Public Relations}

Manajemen Public Relations (PR) merupakan suatu fungsi manajemen yang dijalankan oleh PR dalam organisasi. Menurut Morissan (2014:108) fungsi manajemen pada humas menghendaki agar setiap perencanaan memuat tujuan yang konkret sehingga pada saat evaluasi nantinya semua kegiatan humas yang direncanakan dapat diukur. Dalam PRSA (2012:22) berbagai jenis proses atau langkah yang digunakan dalam manajemen PR bedasarkan organisasi yang berbeda dan penulis yang berbeda menggunakan akronim yang berbeda, pada penelitian ini berfokus pada tiga tahap yakni perencanaan, implementasi dan evaluasi.

\section{Perencanaan (Planning)}

Rumusan perencanaan program PR yang matang akan menciptakan suatu program PR yang efektif. Menurut George dalam Morrisan (2014:153) menjelaskan bahwa hal yang terpenting adalah bahwa strategi dipilih untuk mencapai suatu hasil tertentu sebagaimana dinyatakan dalam tujuan atau sasaran yang sudah ditetapkan. Proses perencanaan dan penetapan program humas ditentukan dalam menetapkan peran dan misi perusahaan yang hendak ingin ditampilkan pada media digital, menentukan wilayah sasaran yang akan menjadi area tujuan pesan, mengidentifikasi dan menentukan indikator efektivitas, memilih dan menentukan sasaran atau hasil yang ingin dicapai.

\section{Implementasi (Implementation)}

Setelah data terkumpul dan menetapkan rencana dilanjutkan dengan bagian implementasi atau pelaksanaan. Menurut Morissan (2014:190) Dalam tahapan implementasi adapun hal penting yang harus diperhatikan praktisi humas ketika berkomunikasi atau melakukan komunikasi yang terkait dengan membingkai pesan, nilai berita yang meliputi dampak (impact), kedekatan (proximity), kecepatan (timeliness), terkenal (prominence), hal-hal baru (novelty), konflik, semiotika, simbol dan streotip.

3. Evaluasi (Evaluation)

Tahapan setelah pelaksanaan dilakukan yakni evaluasi yang mengukur capaian-capaian dari implementasi yang telah dilaksanakan. Menurut Morrisan (2014:225) evaluasi kehumasan terkait dengan pertanyaan bagaimana menilai suatu program kehumasan apakah sudah berhasil atau belum? Apa kriteria yang digunakan untuk menilai program kehumasan sudah berhasil atau masih harus diperbaiki? Pada evaluasi program kehumasan yang dapat dibagi atas tiga tahapan utama yaitu evaluasi tahapan persiapan, evaluasi tahap pelaksanaan, evaluasi tahap dampak atau efek.

\section{METODE PENELITIAN}

Metode penelitian yang digunakan dalam penelitian adalah deskriptif kualitatif dengan menggunakan pendekatan studi kasus. Robert (2013:3) mendeskripsikan bahwa studi kasus bertujuan untuk mengetahui bagaimana mendesain dan menyelenggarakan studi-studi kasus tunggal atau multikasus bagi suatu penelitian. Adapun teknik pengumpulan data yang dipilih adalah dokumen dan wawancara mendalam. Data dokumen diperoleh dari data-data laporan, media dan materi-materi komunikasi RS JIH Yogyakarta; dan wawancara mendalam dilaksanakan dengan triangulasi narasumber yakni Tim Humas selaku konseptor, Agensi RWE selaku admin dan beberapa pasien Rumah Sakit “JIH” selaku pengguna layanan. Teknik analisis data dilakukan dimulai dari reduksi data, penyajian data hingga penarikan kesimpulan.

\section{HASIL DAN ANALISIS}

\section{a. Perencanaan Digital Public Relations Rumah Sakit "JIH"}

Tahapan pertama yang dideskripsikan dalam pengelolaan digital PR adalah tahap perencanaan. Perencanaan disusun untuk menentukan strategi kegiatan PR serta pengambilan keputusan dengan melihat segala aspek yang menyangkut dengan program PR. Tahapan perencanaan menghimpun penjelasan mengenai skema dan alur pengajuan program dalam input perencanaan selain output perencanaan isi pesan atau konsep yang akan ditayangkan, penentuan media sosial yang digunakan serta beberapa uji untuk melihat kembali perencanaan.

Menurut Sopian (2016:212), perencanaan suatu kegiatan yang diusulkan pihak PR kepada pimpinan perusahaan harus dapat meyakinkan bahwa kegiatan tersebut perlu bahkan penting untuk dilaksanakan. Penentuan dari media digunakan oleh perusahaan ditentukan melalui media digital yang banyak diminati oleh masyarakat serta melihat segmentasi dari karakter pengguna di media sosial yang akan dipilih. Penentuan waktu dari tayangan yang akan ditampilkan juga ditentukan melalui waktu prime time dari masing-masing media digital yang digunakan misalkan pada media sosial dilihat dari media sosial analisis yang ada pada tiap media sosial untuk menunjukan waktu yang tepat untuk 
penayangan. Bentuk dari realisasi dari kegiatan digital PR dapat dilihat dari langkah-langkah dari perencanaan tersebut dirancang, dengan melihat bagaimana alur atau skema pembentukan perencanaan kegiatan digital PR.

\section{Input Perencanaan}

Proses awal yang dilakukan oleh Rumah Sakit "JIH” dalam bagian perencanaan adalah dengan menentukan urutan tindakan yang akan dilakukan untuk membentuk suatu kegitan digital Public Relations. Alur atau skema untuk perencanaan kegiatan terdapat 3 (tiga) tahapan.

Bagan 3.1. Proses alur pengusulan rencana di Rumah Sakit "JIH"

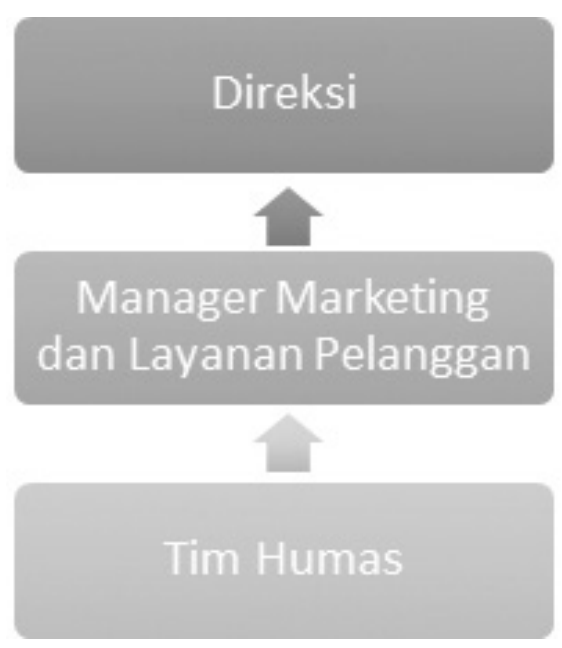

Melalui proses awal dimana ide dari Department Humas dibentuk dan dimatangkan dengan konsep hingga pelaksanannya dengan tim. Kemudian konsep tersebut dinaikan ke wewenang diatas tim Humas yakni Manager Marketing dan Layanan dan Pelanggan untuk konfirmasi. Setelah mendapat konfirmasi, apabila kegiatan menyangkut dengan pembiayaan dinaikan kembali ke bagian yang diatas Manager Marketing dan Layanan dan Pelanggan. Adapun skema lain yang menjelaskan bagaimana proses atau alur pengonsepan postingan yang akan ditayangkan melalui media digital yang dimiliki oleh Rumah Sakit "JIH" yang disebut dengan Editorial Plan.

Bagan 3.2 Skema penyusunan Editorial Plan
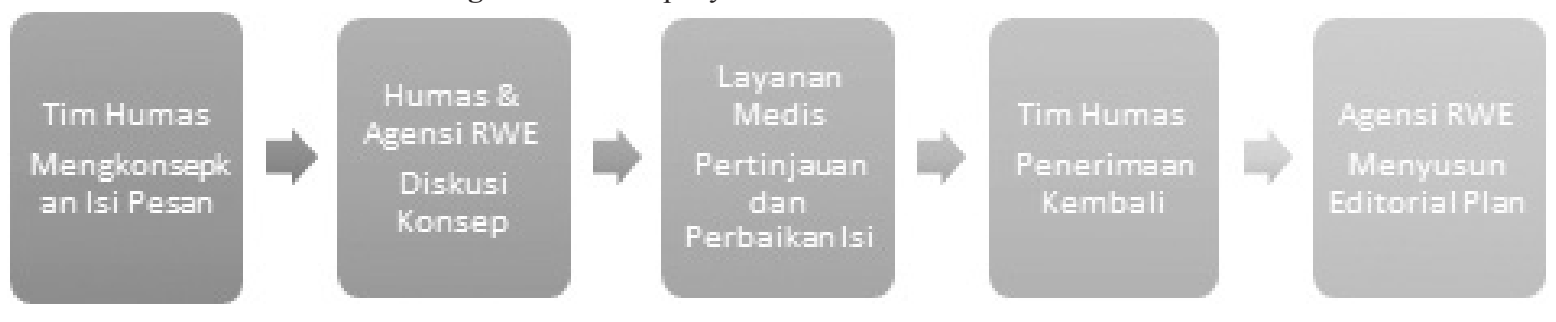

Melalui penggunaan editorial plan yang telah disusun setiap minggunya ditentukan bagaimana skema perencanaan yang akan dilakukan. Berbeda pada Bulan Januari hingga Agustus editorial plan belum digunakan sebagai skema perencanaan kegiatan digital PR, skema perencanaan pada periode itu lebih singkat dan spontanitas. Namun mulai pada kuatral keempat tahun 2017 pada saat Humas mulai bekerja sama dengan Agensi RWE penggunaan editorial plan mulai digunakan untuk memaksimalkan perencanaan konten dan konsep yang akan ditayangkan pada media sosial milik Rumah Sakit "JIH".

\section{Output Perencanaan}

a) Penentuan isi pesan dan tujuan

Perencanaan isi pesan yang akan ditampilkan oleh Rumah Sakit "JIH" melalui media digitalnya pada umumnya bedasarkan dari kalender medis yang dimiliki rumah sakit.

Tabel 3. Perencanaan Digital PR Rumah Sakit “JIH” Tahun 2017

\begin{tabular}{|l|l|l|l|}
\hline No. & Bulan & \multicolumn{1}{|c|}{ Tema } & \multicolumn{1}{c|}{ Perencanaan Pesan } \\
\hline 1. & Januari & Sosialisasi Mother Class & $\begin{array}{l}\text { Mother Class bulan Januari oleh dr. Mitta Prana, Sp.OG tentang kesuburan } \\
\text { organ reproduksi dalam persiapan program kehamilan. }\end{array}$ \\
\hline 2. & Februari & Sosialisasi Mother Class & $\begin{array}{l}\text { Mother Class oleh dr. M. Nurhadi Rahman, tentang menjaga kesehatan } \\
\text { Ibu Hamil dan Janin. Ibu yang sedang hamil harus menyiapkan fisik dan } \\
\text { mental sejak kehamilan sampai persalinan. }\end{array}$ \\
\hline
\end{tabular}




\begin{tabular}{|c|c|c|c|}
\hline 3. & Maret & $\begin{array}{l}\text { Publikasi Kegiatan } \\
\text { Internal dan Kerjasama }\end{array}$ & $\begin{array}{l}\text { - Sosialisasi pentingnya Cuci Tangan yang benar sesuai standar WHO. } \\
\text { - Ulang Tahun ke } 10 \text { untuk Sasana Taichi JIH. } \\
\text { - Kegiatan pada Car Free Day Hasil kerjasama RS JIH dan Tribun News } \\
\text { Jogja } \\
\text { - Seminar Fertilitas, hasil kerjasama RS JIH bersama Morula. } \\
\text { - RS JIH bersama SMAN 3-Padmanaba Jogjakarta mengadakan donor } \\
\text { darah } \\
\text { - Sosialisasi dr. Prabata berbagi tentang Membiasakan Gaya Hidup Sehat } \\
\text { Sejak Dini. } \\
\text { - Kegiatan Donor Darah di RS JIH }\end{array}$ \\
\hline 4. & April & $\begin{array}{l}\text { Informasi Pelayanan } \\
\text { dan Kegiatan Rumah } \\
\text { Sakit "JIH" }\end{array}$ & $\begin{array}{l}\text { - Informasi RS JIH akan tetap buka pada tanggal } 14 \text { April } 2017 \text { dan } 1 \text { Mei } \\
2017 . \\
\text { - Rumah Sakit JIH dipercaya sebagai Official Medical Team pada konser } \\
\text { The Hitman David Foster and Friends di Grand Pacific Hall Yogyakarta. } \\
\text { - RS JIH dan Morula IVF Jakarta melakukan Seminar Infertilitas di } \\
\text { Auditorium RS JIH. } \\
\text { - Mother Class oleh dr. Ikhwan Zein Sp.KO untuk membentuk tubuh } \\
\text { menjadi sehat dan ideal setelah melahirkan. } \\
\text { - Peringatan Hari Kartini, RS JIH untuk pasien Rumah Sakit "JIH" }\end{array}$ \\
\hline 5. & Mei & $\begin{array}{l}\text { Informasi Pelayanan } \\
\text { dan Kegiatan Rumah } \\
\text { Sakit "JIH" }\end{array}$ & $\begin{array}{l}\text { - RS JIH bekerjasama dengan PERDATIN DIY mengulas tentang Code } \\
\text { Blue System, aktivasi emergency, strategi pencegahan dan resusitasi henti } \\
\text { jantung di rumah sakit. } \\
\text { - Seminar oleh dr. M Nurhadi Rahman Sp.OG dalam Hypnobirthing. } \\
\text { - Rumah Sakit JIH mengikuti lomba Hand Hygiene Dance di Jogja PERSI } \\
\text { Expo dan menjadi Juara. } \\
\text { - Informasi RS JIH akan tetap buka pada tanggal } 11 \text { Mei } 2017 \text { dan tanggal } \\
25 \text { Mei } 2017 . \\
\text { - Seminar dan lomba-lomba dalam rangka mengawal tumbuh kembang } \\
\text { anak di usia emas nya, hasil kerjasama RS JIH dan HUKI. } \\
\text { - Seminar oleh dr. M Khalimur Rouf Sp. PD mengenai tips menjalankan } \\
\text { Ibadah Puasa Ramadhan bagi Penderita Diabetes. } \\
\text { - Seminar oleh dr. Sari Sp.A tentang tumbuh kembang anak di usia emas. }\end{array}$ \\
\hline 6. & Juni & Ramadhan & $\begin{array}{l}\text { - Ngaji Sehat on Facebook JIH di Lobby Timur RS JIH live streaming di } \\
\text { Facebook di alamat @tribunjogjafanspage. } \\
\text { - Buka Puasa dan Pemberian Santunan di Rumah Yatim Dhuafa Al Ma'ruf } \\
\text { Bersama RS JIH. } \\
\text { - Ramadhan Special Offer yang berlaku sampai } 15 \text { Juli } 2017 .\end{array}$ \\
\hline 7. & Juli & Kanker Serviks & Seminar oleh dr.Enny P Sp.OG, Kanker Serviks. \\
\hline 8. & Agustus & Kemerdekaan & $\begin{array}{l}\text { - Seminar Mother Class daam suasana kemerdekaan } \\
\text { - Aksi Donor Sarah yg di selenggarakan oleh PMI dan RS JIH }\end{array}$ \\
\hline \multirow[t]{4}{*}{9.} & \multirow[t]{4}{*}{ September } & $\begin{array}{l}\text { Minggu \#1 : Hidup } \\
\text { Sehat }\end{array}$ & $\begin{array}{l}\text { Screening rasio lemak dengan Body Composition Analyzer di "JIH" } \\
\text { Healthy Life Center. }\end{array}$ \\
\hline & & $\begin{array}{l}\text { Minggu \#2 : Palang } \\
\text { Merah Indonesia (PMI) } \\
\text { \& Darah }\end{array}$ & $\begin{array}{l}\text { Peringatan Hari Palang Merah Indonesia } \\
\text { Manfaat donor darah } \\
\text { Edukasi mengenai kelainan darah atau gangguan hematologi } \\
\text { Edukasi golongan darah }\end{array}$ \\
\hline & & \begin{tabular}{|l} 
Minggu \#3 : JIH Mobile \\
App
\end{tabular} & Pemanfaatan JIH Mobile App serta cara menggunakan. \\
\hline & & $\begin{array}{l}\text { Minggu \#4 : Kesehatan } \\
\text { Jantung }\end{array}$ & $\begin{array}{l}\text { Hari Jantung Sedunia (World Heart Day) } \\
\text { Edukasi mengenai palpitasi } \\
\text { Edukasi pengaruh kopi terhadap Jantung } \\
\text { Edukasi denyut jantung serta turorial menghitung denyut. }\end{array}$ \\
\hline \multirow[t]{4}{*}{10.} & \multirow[t]{4}{*}{ Oktober } & $\begin{array}{l}\text { Minggu \#1: JIHealthy } \\
\text { Center }\end{array}$ & $\begin{array}{l}\text { Soft launching layanan JIH Healthy Life Center dan penjelasan Healthy } \\
\text { Life Center (HLC). }\end{array}$ \\
\hline & & $\begin{array}{l}\text { Minggu \#2 : Kanker } \\
\text { Payudara }\end{array}$ & $\begin{array}{l}\text { Bulan kesadaran kanker payudara. } \\
\text { Edukasi Kanker payudara dan serviks. } \\
\text { Seminar oleh dr. Mardiyah, Sp.PD-KHOM tentang kanker payudara. } \\
\text { Kegiatan Aksi Peduli Kanker Payudara \#JogjaGoesPink }\end{array}$ \\
\hline & & Minggu \#3 : Menopause & $\begin{array}{l}\text { Peringatan Hari Menopause Sedunia, penjelasan mengenai menopause, } \\
\text { edukasi indikasi emosional dan fisik, penjelasan hot flashes, gejela } \\
\text { menopause dini. }\end{array}$ \\
\hline & & $\begin{array}{l}\text { Minggu \#4 : Medical } \\
\text { Check Up }\end{array}$ & $\begin{array}{l}\text { Edukasi untuk melakukan cek kesehatan secara berkala, persiapan sebelum } \\
\text { medical check up, cek kesehatan yang tepat buat laki-laki dan perempuan. }\end{array}$ \\
\hline
\end{tabular}




\begin{tabular}{|l|l|l|l|}
\hline 11. & November & $\begin{array}{l}\text { Minggu \#1-2: } \\
\text { Kesehatan Pria }\end{array}$ & $\begin{array}{l}\text { Edukasi gerakan Movember } \\
\text { Edukasi Undescended testis } \\
\text { Seminar oleh dr. P. Yuri, Sp.U dari Poli Urologi Rumah Sakit “JIH" }\end{array}$ \\
\cline { 3 - 4 } & Minggu \#3-4 : Diabetes & $\begin{array}{l}\text { Peringatan Hari Diabetes Dunia. } \\
\text { Edukasi diabetes melitus (DM) } \\
\text { Seminar oleh Ibu Kartika Nur Fitriani, S.Gz, Dietizien, MPH (Kepala Unit } \\
\text { Gizi Rumah Sakit "JIH") untuk mencegah terjadinya diabetes. }\end{array}$ \\
\hline 12. & Desember & $\begin{array}{l}\text { Minggu \#1-2: HIV/ } \\
\text { AIDS }\end{array}$ & $\begin{array}{l}\text { Penjelasan mengenai HIV atau Human Immunodeficiency Virus dan AIDS } \\
\text { atau Acquired Immune Deficiency Syndrome, tiga tahapan dan pencegahan } \\
\text { HIV/AIDS. }\end{array}$ \\
\cline { 3 - 5 } & Minggu \#3-4: Khitan & Edukasi Fimosis, Edukasi pentingnya Khitan dan Promo Paket Khitan. \\
\hline
\end{tabular}

Sumber : Dokumen Humas \& Layanan Pelanggan RS “JIH”, 2017

Berdasarkan pada tabel di atas dapat diperhatikan bahwa perencanaan pada tahun 2017 mengalami transisi perubahan yang tampak terlihat dimulai dari kuatral keempat yakni dimulai dari bulan September 2017. Perencanaannya mulai dilakukan secara mingguan, dan tersusun lebih rapi mengikuti kalender medis. Pada bulan Januari hingga Agustus 2017 perencanaan media digital Rumah Sakit "JIH" secara umum terlihat lebih eventual disesuaikan dengan kegiatan yang diadakan di rumah sakit terkait dengan penanggalan tersebut.

b) Pemilihan media digital yang digunakan

Media digital yang digunakan oleh Rumah Sakit "JIH" antara lain website perusahaan, autoresponder pada e-mail, kartu nama elektronik pada e-mail, e-newsletter, dan forum seperti facebook, twitter, dan instagram. Penggunaan website perusahaan merupakan salah satu permulaan penggunaan media digital bagi Rumah Sakit “JIH”, sebelum adanya media sosial yang hadir dalam masyarakat. Melalui media digital tersebut Rumah Sakit "JIH” dapat menjangkau berbagai kalangan pada masyarakat.

\section{Review Perencanaan}

Sebelum rencana tersebut dilaksanakan sebagai implementasi, Tim Humas kembali merevisi sebelum rencana tersebut seutuhnya dilaksanakan menjadi suatu program. Pesan yang ditampilkan pada media digital harus memperhatikan sifat dan ruang lingkup kesesuaian dengan peran dan misi Rumah Sakit "JIH". Peran perusahaan yang bergerak pada bidang kesehatan dan pelayanan masyarakat, harus menjadi dasar utama bagaimana pesan yang akan ditampilkan pada media digital, begitu juga dengan misi dari perusahaan yang dijelaskan sebagai rumah sakit yang membangun institusi syariah di bidang pelayanan kesehatan menyesuaikan pesan dengan sasaran dan target

Adapun tinjauan yang harus diperhatikan dalam penyusunan yang merupakan dasar bagi area tujuan pesan yang akan disampaikan. Hal ini merupakan cara ideal untuk menyesuaikan pesan yang terkandung dalam setiap tayangan dengan target ataupun sasaran dari pesan tersebut. Dalam kegiatan digital PR Rumah Sakit "JIH" pihak humas menentukan sasaran dan target dari kegiatan bersifat nasional yaitu informasi menjangkau masyarakat secara nasional.

Tabel 3.2. Segmentasi Pasar Rumah Sakit "JIH"

\begin{tabular}{|l|l|l|}
\hline Variabel & Kategori & Segmentasi Pasar \\
\hline \multirow{5}{*}{ Segmentasi Geografis } & Wilayah & Seluruh Indonesia \\
\cline { 2 - 3 } & Ukuran Kota & Metropolitan, Kota Besar, Kota Kecil. \\
\cline { 2 - 3 } & Kepadatan Wilayah & Kota, Pinggir Kota, Kota Lama. \\
\cline { 2 - 3 } & Iklim & Sedang, Panas, Lembab, Berhujan. \\
\hline \multirow{5}{*}{ Segmentasi Demografis } & Umur & $18-34,35-49,50-64$, diatas 64 \\
\cline { 2 - 3 } & Jenis Kelamin & Pria, Wanita \\
\cline { 2 - 3 } & Status Perkawinan & Lajang, Kawin dll \\
\cline { 2 - 3 } & Penghasilan & $>$ Rp. 2 juta \\
\cline { 2 - 3 } & Pendidikan & - \\
\cline { 2 - 3 } & Pekerjaan/Jabatan & Mahasiswa, profesional, militer dll \\
\hline Segmentasi Psikografis & Kepribadian & Ekstrovert, Introvert, Ambivert. \\
\cline { 2 - 3 } & Gaya Hidup & Pencari status, ahli merek. \\
\hline Segmentasi Sosio-Kultural & Kelas Sosial & Mengah Atas \\
\hline
\end{tabular}

Sumber : Data Humas \& Layanan Pelanggan Rumah Sakit “JIH”,2017 


\section{b. Implementasi Digital Public Relations di Rumah Sakit "JIH"}

Setelah menetapkan rencana dilanjutkan dengan pelaksanaan digital public relations. Pemanfaatan media digital yang terhubung dengan internet, jangkauan pesan yang akan disebarkan oleh perusahaan akan menjadi lebih luas jangkauannya. Tidak hanya terbatas pada area lokal, regional maupun nasional namun melalui media digital pesan tersebut dapat menjangkau secara global. Jangkauan area ini meluas dikarenakan sasaran pasien juga meluas sampai dengan tingkat nasional; tidak terbatas pada jangkauan area D.I Yogyakarta maupun area pulau Jawa. Adapun langkahlangkah pelaksanaan digital PR RS JIH adalah :

\section{Penjadwalan (scheduling)}

Skema penjadwalan dilakukan dengan melihat prime time pada masing-masing channel. misalkan pada facebook memiliki waktu jam 12 siang, yang berarti waktu yang tepat untuk memposting di facebook. Sedangkan pada instagram memiliki prime time jam 6 sore, yang berarti waktu yang tepat untuk menguggah pada waktu demikian di instagram. Prime time bisa dilihat dengan menggunakan analytic tools atau insight yang telah disediakan pada masing-masing channel.

2. Anggaran (budgeting) Pemetaan perencanaan dalam kegiatan digital Public Relations oleh Humas Rumah Sakit "JIH" dengan menyediakan anggaran khusus untuk melaksanakan pengelolaan digital PR dengan nominal yang tidak murah. Penggunaan anggaran tersebut difokuskan untuk penggunaan pihak ketiga dalam pengelolaannya yaitu Agensi RWE selaku eksekutor atau admin dari sosial media resmi yang dimiliki oleh Rumah Sakit "JIH".

3. Pesan-Pesan Digital PR

Pada tahapan implementasi adapun hal penting yang harus diperhatikan praktisi humas ketika pelaksanaan atau melakukan komunikasi yang terkait dengan prinsip-prinsip mengemas pesan yakni membingkai pesan, nilai berita, semiotika, simbol dan streotip. Adapun bentuk framing yang dilakukan oleh Rumah Sakit "JIH" pada media digitalnya ialah dengan mengutamakan tema yang Islami dan Profesional. Strategi framing lainnya yang dilakukan oleh Rumah Sakit “JIH' adalah dengan tidak terlalu banyak menggunakan istilah medis dalam mengemas pesan, meskipun harus menggunakan istilah medis namun diberikan penjelasan yang lebih mudah dipahami oleh audiens.

Penambahan unsur-unsur nilai berita yang termasuk pada dampak, kedekatan, kecepatan, terkenal, hal yang baru, dan konflik pada setiap unggahan yang ditayangkan oleh Rumah Sakit "JIH". Terbukti pada penggunaan nilai berita pada beberapa tayangan yang digunakan oleh Rumah Sakit "JIH" menghasilkan engangement lebih tinggi. Selain pada unsur nilai berita, simbol digunakan untuk menampilkan ciri khas dari perusahaan, Rumah Sakit "JIH" menempatkan logo perusahaan pada kiri atas unggahan dan konten yang ditayangkan disesuaikan dengan tema warna korperat yakni warna biru dengan latar belakang warna putih. Penggunaan streotip juga dimanfatkan dalam implementasi media sosial dengan menggunakan streotip yang baik dan mengindari strotip negatif.

Gambar 1. Pesan Digital PR pada tayangan di Instagram

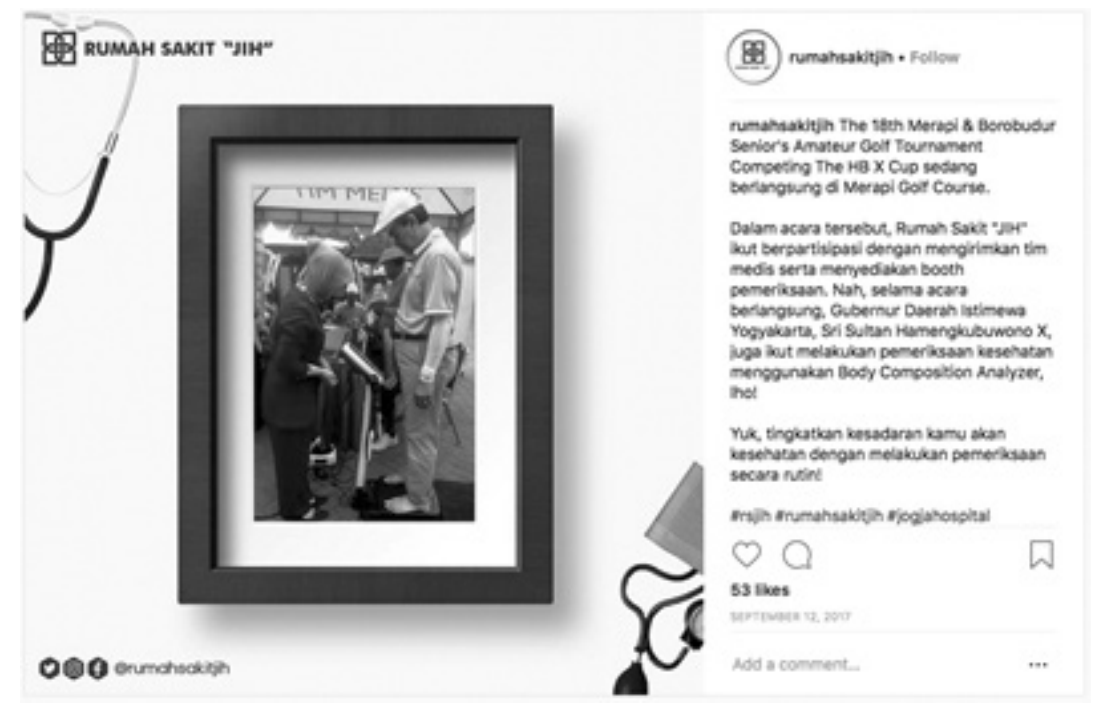

Sumber : Akun instagram Rumah Sakit "JIH"

Pada unggahan yang ditayangkan Rumah Sakit “JIH” pada tanggal 12 September 2017 di instagram, Humas menampilkan citra yang profesional dan islami. Penggunaan nilai berita terkenal dengan menonjolkan tokoh masyarakat Sri Sultan Hamengkubuwono X. Rancangan yang serupa juga ditampilkan pada facebook 
dan twitter dengan mengedepankan unsur-unsur pesan digital PR dalam penayangannya. Namun konsep disesuaikan dengan segmentasi dan fitur pada tiap channel.

Gambar 2. Pesan Digital PR pada tayangan di Fcebook

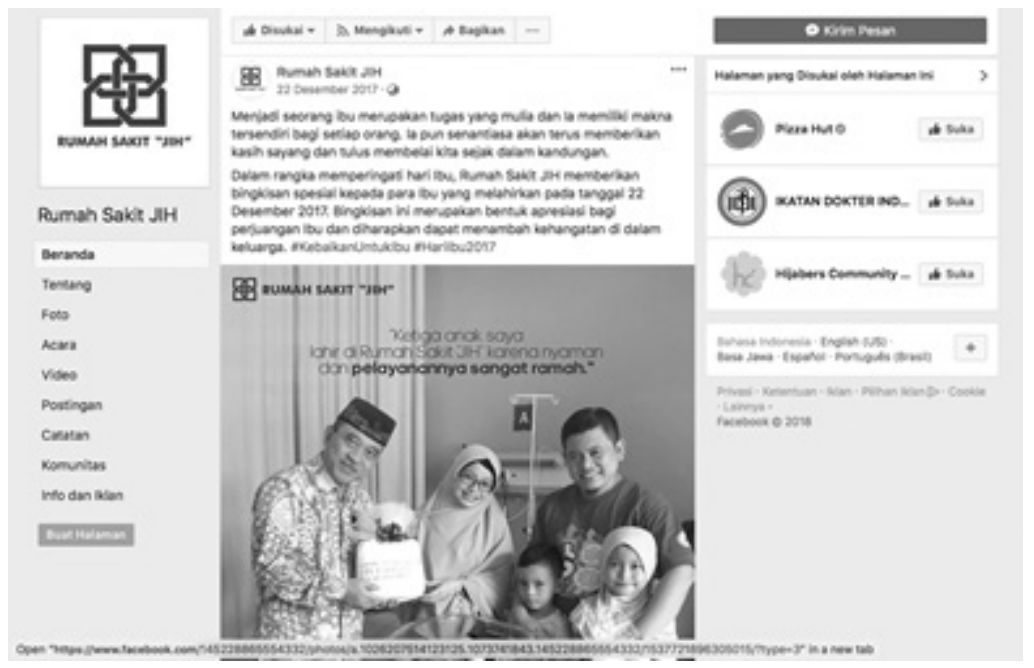

Sumber : Akun facebook Rumah Sakit "JIH"

Konsep pada facebook tidak banyak menggunakan bingkai pada ilustrasinya, hanya mengkombinasikan antara foto dengan narasi. Pada unggahan yang ditayangkan Rumah Sakit “JIH” pada tanggal 22 Desember 2017 di facebook, Humas memanfaatkan penggunaan nilai berita kedekatan dengan menayangkan interaksi manajemen Rumah Sakit “JIH” dengan keluarga pasien pada peringatan Hari Ibu.

\section{c. Evaluasi Digital Public Relations Rumah Sakit “JIH”}

Proses evaluasi merupakan tahapan akhir dari pengelolaan kegiatan Public Relations. Tahapan evaluasi dilakukan setelah implementasi, dilaksanakan untuk mengukur sejauh mana pencapaian dari tindakan komunikasi dilakukan. Menurut Morrisan (2014:225) evaluasi kehumasan terkait dengan pertanyaan bagaimana menilai suatu program kehumasan apakah sudah berhasil atau belum. Pada tahap evaluasi yang dilakukan oleh Rumah Sakit "JIH" lebih memfokuskan pada hasil dari analisis yang sudah tersedia pada masing-masing media sosial yang digunakan.

Hasil evaluasi yang diperoleh juga berbeda-beda tergantung pada fitur yang ditampilkan pada tiap media sosial. Pada facebook hasil evaluasi ditunjukan melalui analytic tools yang didalamnya meliputi hasil dari jumlah likes, komentar, jumlah audiens yang mengklik pada tautan yang ditampilkan, luas jangkauan dari setiap unggahan, jumlah tayangan yakni jumlah berapa kali unggahan tertentu tampil dihalaman audiens serta jumlah konsumsi yang menunjukan berapa kali audiens melihat konten dalam bentuk foto dan video diputar. Bentuk evaluasi yang sama juga dapat diperhatikan pada instagram dimana hasil dari evaluasi dapat ditunjukan melalui instagram insight yang didalamnya kurang lebih sama dengan pada facebook.

Adapun bentuk dari evaluasi dari twitter dapat diperhatikan dari penggunaan twitter activity yang sudah tersedia pada twitter. Adapun dari penggunaan analisa tersebut didalamnya termasuk impression yaitu jumlah berapa kali audiens melihat konten tersebut, total engagement yaitu jumlah audiens yang berinteraksi pada tweet tertentu, media engagement juga berapa kali orang mengeklik pada konten gambar atau video, jumlah orang yang memberikan balasan pada konten tersebut, jumlah yang menyukai tweet tersebut serta analisis lain adalah jumlah dari orang yang mengeklik tagar yang disertakan pada tweet tersebut.

\section{KESIMPULAN}

Perencanaan digital public relations menggunakan editorial plan yang disusun setiap minggunya sehingga proses perencanaan lebih panjang dan tertata dengan baik. Media sosial yang digunakan oleh Rumah Sakit "JIH" dalam kegiatan digital PR perusahaan adalah Facebook, Instagram dan Twitter. Pemilihan media sosial tersebut bedasarkan segmentasi dari masing-masing karakter pengguna dari masing-masing media sosial. Instagram merupakan media sosial dari Rumah Sakit "JIH" yang memiliki traffic yang lebih tinggi dibandingkan kedua media sosial lainnya namun dari segi jumlah pengikut Facebook memiliki jumlah terbanyak.

Pelaksanaan digital PR Rumah Sakit “JIH” dilakukan berdasarkan editorial plan dengan petunjuk timeline yang ada didalamnya. Waktu dari penayangan masing-masing media sosial bedasarkan waktu dari prime time pada masingmasing media sosial. Sementara itu pelaksanaan evaluasi dalam pengelolaan digital public relations Rumah Sakit "JIH" dilakukan bedasarkan data yang dihimpun dari media sosial analisis yang sudah tersedia pada setiap media sosial yang digunakan. Melalui penggunaan data tersebut menunjukan hasil konten apa yang minati oleh audiens melalui jumlah yang 
menyukai, memberi komentar, membagikan, jangkauan dari konten, peningkatan jumlah pengikut dan bentuk interaksi lainnya yang dihasilkan dari tayangan konten.

\section{DAFTAR PUSATAKA}

Arikunto, Suharsimi. 2006. Prosedur Penelitian Suatu Pendekatan Praktik. Jakarta: Rineka Cipta.

Kartikasari, Nita. 2017. VIRAL: Gebrakan Kekinian Public Relations Di Era Digital. Jakarta: PT. Gramedia Pustaka Utama.

Kriyantono, Rachmat. 2008. Public Relations Writing: Teknik Produksi Media Public Relations dan Publisitas Korporat. Jakarta: Kecana.

Lexy J, Moeleong. 2000. Metodologi Penelitian Kualitatif. Bandung: PT. Remaja Rosdakarya.

Middleberg, Don. 2001. Winning PR In The Wired Word: Powerful Communications Strategies for the Noisy Digital Space. New York: McGraw-Hill.

Lee, Monle dan Carla Johnson. 2007. Prinsip-Prinsip Periklanan Dalam Perspektif Global. Diterjemahkan oleh Haris Munandar dan Dudi Priatna. Jakarta: Kencana Prenada Media.

Morissan. 2014. Manajemen Public Relations: Strategi Menjadi Humas Profesional. Jakarta: Kencana.

Nasrullah, Rulli. 2014. Teori dan Riset Media Siber (Cybermedia). Jakarta: Prenamedia Group.

Nasution. 2003. Metodologi Research (Penelitian Ilmiah). Jakarta: Bumi Aksara.

Onggo, Bob Julius. 2004. Cyber Public Relations. Jakarta: Elex Media Komputindo.

Onggo, Bob Julius. 2004. E-PR: Menggapai Publisitas di Era Interaktif Lewat Media Online. Yogyakarta: ANDI.

Pawito. 2008. Penelitian Komunikasi Kualitatif. Yogyakarta: LKIS.

Public Relations Society of America (PRSA). 2016. APR Study Guide: for the Examination for Accreditation in Public Relations. USA: Universal Accreditation Board.

Ruslan, Rosady. 2013. Metode Penelitian: Public Relations dan Komunikasi. Jakarta: PT. Raja Grafindo Persada.

Ruslan, Rosady. 2016. Manajemen Public Relations \& Media Komunikasi: Konsepsi dan Aplikasi: Konsepsi dan Aplikasi. Jakarta: Rajawali Pers.

Sopian. 2016. Public Relations Writing: Konsep, Teori, Praktik. Jakarta : PT Grasindo.

Sugiyono. 2008. Metode Penelitian Kuantitatif Kualititatif dan R\&D. Bandung: Alfabeta.

Suryabrata, Sumadi. 1987. Metode Penelitian. Jakarta: Rajawali.

Ulber, Silalahi. 2009. Metode Penelitian Sosial. Bandung: PT. Refika Aditama.

Yin, Robert K. 2013. Studi Kasus: Desain dan Metode. Jakarta : PT. Raja Grafindo Persada

\section{SUMBER INTERNET}

Diakses melalui http://mix.co.id/marcomm/brand-insight/tahun-2015-digital-pr-makin-berperan-besar pada tanggal 22 Februari 2018

Diakses melalui https://news.detik.com/berita-jawa-tengah/d-3876492/pengusaha-as-tertarik-investasi-rumah-sakit-diyogyakarta pada tanggal 23 April 2018

Diakses melalui https://news.detik.com/berita-jawa-tengah/d-3876492/pengusaha-as-tertarik-investasi-rumah-sakit-diyogyakarta pada tanggal 23 April 2018

Diakses melalui http://www.tribunnews.com/bisnis/2018/01/26/public-relation-berperan-dalam-membangun-relasidengan-warga-net pada tanggal 2 Maret 2018

Daftar Rumah Sakit diakses melalui pada tanggal 3 Mei 2018 http://sirs.yankes.kemkes.go.id/rsonline/Peta_list.php?ctlS earchFor=Sleman\&simpleSrchFieldsComboOpt=KAB\%2FKOTA\&simpleSrchTypeComboNot=\&simpleSrchTy peComboOpt $=$ Equals $\& a=$ integrated $\& i d=1 \&$ criteria $=$ and

Diakses melalui https://www.wartaekonomi.co.id/read172018/layanan-rumah-sakit-pondok-indah-kini-hadir-melaluiaplikasi.html pada tanggal 1 Mei 2018 
Diakses melalui http://www.rs-jih.co.id pada tanggal 7 Juni 2018

Diakses melalui https://web.facebook.com/Rumah-Sakit-JIH-145228865554332/?ref=br_rs pada tanggal 7 Juni 2018

Diakses melalui https://witter.com/RUMAHSAKITJIH pada tanggal 7 Juni 2018

Diakses melalui https://www.instagram.com/rumahsakitjih/ pada tanggal 7 Juni 2018

\section{JURNAL}

Beni Erliansyah, Nova Yohana (2017) Universitas Riau. Manajemen Pengelolaan Cyber Public Relations Dalam Mewujudkan Good Governance Pemerintah Kota Payakumbuh. Diakses melalui https://jom.unri.ac.id/index.php/ JOMFSIP/article/view/15647 pada tanggal 11 Mei 2018

Berghs School of Communication \& Mynewsdesk. 2016. Global Study Sets Stage For The Digital PR Revolution. Stockholm. Diakses melalui http://pages.mynewsdesk.com/rs/763-HDU-978/images/2016-PR-RevolutionPart-1.pdf?utm_medium=email\&utm_source=solus\&utm_campaign=PR-Revolution-Part1-uk1216\&mkt_tok= eyJpIjoiTW1NNU5ETTFZall5TnpkbSIsInQiOiJFZkUyclFidmR3MkJyNG5YM1B0ZktJSHIMeXNvWkRYM WFtZWhMcDBvdm5KakR2MVhWZUk0Q1wve314SUx0NGV0MDBUOHViSkdsbDh4MTRYVU1iV3RxU2t qaHpQRm1jb3FMZXRDbzZMdkwraFdWZFwvM1JnelkyZXBWUVZ3ZWUwWDFhIn0\%3D pada tanggal 20 Februari 2018

Kuspuji Catur Bagus Wicaksono (2013) Binus University. Mengukur Efektivitas Social Media Bagi Perusahaan. Diakses melalui https://www.google.com/url?sa=t\&rct=j\&q=\&esrc=s\&source=web\&cd=1\&cad=rja\&uact=8\&ved=0a hUKEwj24dC28Z3cAhWR62EKHaYbAp8QFggyMAA\&url=http\%3A\%2F\%2Fjournal.binus.ac.id\%2Findex. php\%2FBBR\%2Farticle\%2Fdownload\%2F1419\%2F1278\&usg=AOvVaw1NRatDLWouu3PZ9fm6PA09 pada tanggal 3 Juli 2018

Fajar Syuderajat, Kenanga Puspitasari (2017) Universitas Padjajaran. Pengelolaan Media Sosial Oleh Unit Corporate Communication PT GMF Aeroasia. Diakses melalui http://journals.ums.ac.id/index.php/komuniti/article/ view/4173 pada tanggal 10 Mei 2018

Infografis : Penetrasi \& Perilaku Pengguna Internet Indonesia 2017 oleh Asosiasi Penyelenggara Jasa Internet Indonesia. Diakses melalui https://web.kominfo.go.id/sites/default/files/Laporan\%20Survei\%20APJII_2017_v1.3.pdf pada tanggal 20 Februari 2018

Leaning, Brittany. 2013. An Introductory Guide: How To Use Twitter For Business. MA, USA : HubSpot Ltd. Diakses melalui http://cdn2.hubspot.net/hub/53/file-364539149-pdf/Intro_Twitter_Business.pdf pada tanggal 15 Mei 2018

My Community Life at Kingston Council. 2015. Facebook User Guide. Victoria, Australia : The City of Kingston. Diakes melalui http://www.mycommunitylife.com.au/files/67388f2b-9eee-4293-a117-a4c60105dbc6/My-CommunityLife-User-Guide-Facebook-June-2015.pdf pada tanggal 15 Mei 2018

Simply Measured. 2016. The Complete Guide to Facebook Analytics : How To Analyze The Metrics That Matter. Seattle, USA : Simply Measured Ltd. Diakses melalui http://get.simplymeasured.com/rs/simplymeasured2/images/ FacebookeBookSimplyMeasured.pdf pada tanggal 15 Mei 2018

Simply Measured. 2017. Simply Measured's Ultimate 2017: Instagram eBook. Seattle, USA : Simply Measured Ltd. Diakes melalui https:/get.simplymeasured.com/rs/135-YGJ-288/images/2017_1-Ultimate-Instagram_eBookFinal2.pdf pada tanggal 15 Mei 2018

@twitteruk. 2012. Twitter For Your Business : A Guide To Get Started. UK : Twitter Inc. Diakses melalui https://business. twitter.com/en.html pada tanggal 15 Mei 2018 
